\title{
GENDER VARIATIONS FAVOURING MALE STUDENTS IN PERCEIVED NATURE OF LEARNING MOLE CONCEPT
}

\author{
Kenneth Adu-Gyamfi, Rejoice Elikem Vorsah \\ University of Cape Coast, Ghana \\ E-mail: kenneth.adu-gyamfi@ucc.edu.gh, vorsahrejoice024@gmail.com
}

9

\begin{abstract}
A good number of instructional strategies are identified to help students overcome their learning difficulties in the mole concept. However, Ghanaian senior high school students continue to have difficulties in the mole concept. Hence, there was the need to examine the perceived nature of learning the mole concept in the perspectives of male and female students. An explanatory sequential mixed methods design was adopted to collect quantitative and qualitative data. The students, selected through a multistage sampling procedure from four schools, responded to questionnaire and interview guide. Through independentsamples t-test statistics it was established that though students were full of uncertainty about the perceived nature of the mole concept that of males differed from their female counterparts. Hence, chemistry teachers should create learning environment conducive enough for male and female students to overcome their uncertainty in the mole concept.
\end{abstract}

Keywords: chemistry teachers, gender variations, learning mole concept, perceived nature

\section{Introduction}

The term molar, originated from the Latin word 'moles' meaning 'a large mass', was first introduced into chemistry by German chemist, August Wilhelm Hoffman around 1865. Thereafter, chemists adopted the mole concept as a more convenient way to deal with large mass of molecules or ions in a given sample (Ebbing \& Gammon, 2017) and that the number of moles of atoms is the number of a modest size even less than one (Petrucci et al., 2017). This is because it was difficult for chemists to count directly the large amounts of particles at the microscopic level (Furio et al., 2002; Indriyanti \& Barke, 2017). "A mole is the quantity of a given substance that contains as many molecules or formula units as the number of atoms in exactly $12 \mathrm{~g}$ of carbon-12" (Ebbing \& Gammon, 2017, p. 73). The mole concept is a conversion factor for a given problem-solving involving number of atoms, molar mass, Avogadro's constant, , and percent abundance (Petrucci et al., 2017). Students have several questions to ask when dealing with the mole. One of such questions is: When do I multiply or divide using in calculations demanding Avogadro's constant? (Petrucci et al., 2017).

This and other students' questions bring to mind the issue of conceptual difficulties (Furio et al., 2002) in the form of alternative conceptions on mole concept. There are alternative conceptions students have about the mole concept and that when using the mole, it is advisable to specify the formula of the unit to prevent any misunderstanding (Ebbing \& Gammon, 2017). Mulford and Robinson (2002) reported on students' pre-concepts concerning the mole concept and concluded that students' self-developed concepts do not match up with the scientific theories. The students came up with their own theory and logic through the observation in order to shape their ideas. For example, students mistakenly presumed the term mole as a value, whereas it is actually a quantity. This shows that those pre-concepts lead to the formation of 
Kenneth ADU-GYAMFI, Rejoice ELIKEM VORSAH. Gender variations favouring male students in perceived nature of learning mole concept

PROBLEMS

OF EDUCATION IN THE $21^{\text {st }}$ CENTURY Vol. 80 , No. 1,2022

10

alternative conceptions among the students, and students' scientific language is identified as a contributor to their alternative conceptions. There are difficulties in learning chemical concepts (Bilek et al., 2018; Goes et al., 2020), especially when the specific terminology and language are not differentiated (Barke et al., 2009).

These learning difficulties in chemical concepts could be addressed using an appropriate instructional approach, such as conceptual change approach (Calik et al., 2009; Ozmen, 2007). Because conceptual change approaches take students' prior or pre-existing knowledge into account (Calik et al., 2009), they help students overcome any alternative conception that students bring to classroom on chemical concepts (Ozmen, 2007). However, Mensah et al. (2016) reported that situational, cultural, and educational contexts affected their learning difficulties and conceptual change approaches of chemistry concepts. Hence, some research findings have emerged to examine the perceptions of students on another chemical concept in a Ghanaian context.

Students' minds are deeply grounded with the language they have acquired several years than the new scientific language, which has been picked up in recent lessons. Students feel insecure when using these scientific languages with friends or relatives. For instance, students resort to use the word "weight" instead of "mass" when describing a quantity in the mole concept. Students also think that the mole is a certain mass, a certain number of gas particles, and/or molecules. The mole principal value is a tool that indirectly counts atomic or molecular particles of substances by weighing macroscopic amounts of substances (Indriyanti \& Barke, 2017). These alternative conceptions are sources of poor performances and perceptions about the mole concept.

The study by Hafsah et al. (2014) revealed that students with inadequate understanding of the mole concept performed poorly on stoichiometry problem-solving task and those with adequate understanding of the mole concept performed better on stoichiometry problemsolving tasks. This is because students' academic performance on stoichiometry correlates positively with their conceptual understanding of mole concept (Taha et al., 2014). Also, one of the pre-requisite chemical concepts that Bilek et al. (2018) found from literature to contribute to the complexity and multistage character of balancing chemical equations is the mole concept. According to Sarkodie and Adu-Gyamfi (2015), learning concepts at sub microscopic level are very difficult for students, and "the mole concept works on the sub-micro level of chemistry education than presented in macro and symbolic level" (Indriyanti \& Barke, 2017, p. 5) and that could be the reason why students elsewhere expressed that mole concept is a difficult concept to understand (Voska \& Heikkinen, 2000). Also, the poor mathematics ability, confusion, difficulties in remembering and manipulating the equations, no direct definition of the mole provided, and difficult to relate to real life (Moss \& Pabari, 2016) account for the difficulties and perceptions students have in learning the mole concept.

Dahsah and Coll (2007) reviewed the achievements of 97 students from three secondary schools in Thailand, through standard questionnaire and reported that only $2.0 \%$ of the total respondents were able to comprehend all of the concepts including the mole. This means that students experience challenges in solving problems related to the mole concept by not being able to relate the mole to the number of particles, the mass of substance, and chemical equations. Another study by Kamaruddin et al. (2003) on 18 students of Chemical Education Degree programme noted that only $23.0 \%$ of the students understand chemistry concepts. And of the $23.0 \%$, only $6.0 \%$ understand the concept of atoms, another $6.0 \%$, the concept of molecules, and $11.0 \%$, the concept of ions. For the mole concept and its relationship to chemical equations, students demonstrated very poor conceptual understanding (Furio et al., 2002).

In the United States, mole concept is often regarded as a difficult concept. This observation prevents students from continuing studies in the chemistry subject (Sirhan, 2007). This could be that students are faced with several challenges in dealing with abstract concepts like mole 
concept, requiring problem solving (Hafsah et al., 2014). In Nigeria, the mole concept is a concept students encounter challenges in learning for its high level of abstraction (Okebukola, 2005). Nigerian students, for many decades, performed very poorly on mole concept, involving mathematical and problem-solving skills in the Senior School Certificate Examination (SSCE) (Zephrinus \& Phoebe, 2015). That is, students usually find it too tedious to connect the meaning of the mole concept. Hence, Calik et al. (2009) intervened on 18 male and 26 female students' conceptual understanding of solutions in a grade 9 class in Trabzon, Turkey using analogy activity as a conceptual change approach. Calik et al. reported that both male and female students constructed the scientific concepts of types of solution using the amount of substance dissolved in the solution.

In Ghana, the senior high school (SHS) chemistry curriculum has among its general aims to "produce, analyse, interpret, and evaluate qualitative and quantitative data; solve problems involving quantitative data ..." and "make the subject interesting and motivating through designing hand-on activities for students to enhance their understanding of the subject" (Ministry of Education [MOE], 2010, pp. iv-v). These general aims are to introduce SHS students to the mole concept under carbon- 12 scale, solutions, stoichiometry and chemical equations in year 1; and chemical equilibrium and acids and bases in year 2. Under these chemical concepts, students are to: recognise that the introduction of the carbon-12 scale was the beginning of the quantitative measurement of the amount of substance contained in different materials; demonstrate an understanding of the mole concept and its significance to the quantitative analysis of chemical reaction; demonstrate an understanding of qualitative and quantitative properties of solutions; understand that balanced chemical equations indicate the quantitative relationships between reactants and products involved in chemical changes (MOE, 2010, p. 11); explore acidic and basic solutions qualitatively and quantitatively; and use the principles and practice of titration to solve analytical problems (MOE, 2010, p. 33). Using school-based assessment on these chemical concepts, students are to go through laboratory and project works in the form of practical work, experiment, and investigative study (MOE, 2010) to achieve these objectives related to the mole concept.

The WAEC Chemistry Chief Examiner, assessing these and other objectives on behalf of the government and people of the Republic of Ghana, in 2015 elaborated on the lack of adequate knowledge of subject matter by candidates, lack of understanding of scientific terms in concepts of mole and their difficulty in answering questions that are based on comprehension (WAEC, 2015). The Chemistry Chief Examiner in 2016 further reported on candidates' poor mathematical skills exhibited in chemistry questions especially those on mole concept requiring calculations (WAEC, 2016). Also, in 2017 the Chief Examiner elaborated on candidates' inability to carry out simple calculations in chemistry particularly, the mole concept and mole related questions (WAEC, 2017). Though the Chemistry Chief Examiner has been hammering on students' poor performance in mole concept, no observable change has been realised in the advent of interventions on teaching and learning the concept in the SHS. On the basis of this, it was only imminent to examine the underlying cause of these difficulties in learning mole concept to help develop an alternative way of presenting it to students to enhance their academic achievement in the mole concept.

One of the research areas that can be considered in relation to learning the mole concept is the gender of students. Klinger and Findenig (2014) believed that from of old, there has always been some sort of debate on students' gender and learning of scientific concepts, with female students less likely to be on top (Doulík \& Škoda, 2009). This is because gender stereotyping affects academic aspirations of students (Mburu \& Nyagah, 2012). Hence, there was the need to examine the perceptions of students on the nature of learning the mole concept in relation to gender as male and female science students. Empirically, Shebu (2015) found that after using problem-solving approach on teaching mole concept, there was no difference in achievement 
Kenneth ADU-GYAMFI, Rejoice ELIKEM VORSAH. Gender variations favouring male students in perceived nature of learning mole concept

PROBLEMS

OF EDUCATION IN THE $21^{\text {st }}$ CENTURY Vol. 80 , No. 1, 2022

of male and female students. Mukuta and Banda (2019) took care of the mathematics aspect of mole concept that various research has shown that it makes learning of the mole concept difficult to students. The incorporation of mathematics in teaching the mole concept positively influenced students' academic achievement and attitude, but there were no differences amongst male and female students. Damaso and Banda (2019) found that students' academic performance improved after teaching some aspects of the mole concept through the integration of concept mapping, but there was no difference in the academic performance of male and female students.

According to Furio et al. (2002), as students' difficulties exist in learning the mole concept, a number of research approach the problem looking at students' perception, but there continue to be disparity of viewpoints among chemistry educators and researchers. Hence, the need for another research using mixed methods design on students' perceptions of the mole concept cannot be over-emphasized. This is because almost every nation (including Ghana) is trying to achieve the SDG5, leading to the increased in the number of female students in schools in past 15 years, even in the area of science. The increased in the number of female students may have positively shaped their perceptions of learning the mole concept in the SHS in relation to their male counterparts. Hence, the aim of the current research was to examine whether the gender of the students can affect their perceptions of the nature of learning mole concept in the SHS. To achieve this aim, three research questions guided the research:

1. What is the perceived nature of learning the mole concept among SHS students?

2. How is the perception of male students on the nature of learning the mole concept in the SHS different from their female counterparts?

3. What instructional approaches do students suggest as ideal for teaching the mole concept to SHS students?

\section{Research Methodology}

\section{Research Design}

The research adopted sequential mixed methods approaches. Data were, therefore, collected from SHS students through explanatory sequential mixed methods. This mixed methods approach helped to merge quantitative and qualitative methods to examine the perceptions of students on nature of learning mole concept in relation to their gender, with greater stress quantitatively using the qualitative methods to help explain the perception. At the quantitative phase, data were collected from students through a cross-sectional survey. The students responded to a closed-ended questionnaire on the perceived nature of learning the mole concept in the SHS. The quantitative data were analysed to examine the perceived nature of learning the mole concept using means, standard deviations, percentages, and independentsamples $t$-test. The findings informed the researchers on the male and female students to participate in the qualitative phase and to shape some aspects of the interview guide. At the qualitative phase, based on the difference (if any) in the perceived nature of learning the mole concept, male and female students were selected for interviews on alternative ways of teaching the mole concept. The qualitative data were analysed using themes and percentages. Thereafter, the quantitative findings on the perceived nature of learning the mole concept were summarised and interpreted and the qualitative findings on the suggested alternative ways of teaching the mole concept were summarised and interpreted. Finally, the qualitative findings were used to explain the quantitative results. 
The Central Region was one of the 16 administrative regions of Ghana bordered by Ashanti and Eastern regions to the north, Western region to the west, Greater Accra to the east, and to the south by the Gulf of Guinea. The region was cosmopolitan with total population of 2,859,821 as the fourth most populous region in Ghana. It accounted for $9.3 \%$ of the total population of Ghana (Ghana Statistical Service, 2021). It was predominantly made up of the Akan tribe $(90 \%)$. The Central Region was renowned for its many higher education institutions and an economy based on an abundance of industrial minerals and tourism. For this reason, the region was the hub of SHS education, with some of the best schools in the country that attracted students from all regions of the country. The region had three universities, five public nursing and midwifery training colleges, three colleges of education, and 76 public SHS. All the SHS in the region were some years back renowned for their outstanding performance in the West Africa Senior School Certificate Examinations, but at the moment the performance had dwindled a little bit.

Though there were 76 schools in Central Region, the researchers focused on only the 59 public SHS that offered students elective chemistry. The target population of the study, however, comprised all science students offering chemistry in the schools. The accessible population for the study was made up of all chemistry students in four schools. A multistage sampling procedure was used to select 300 SHS2 students (comprising 54.7\% males and $45.3 \%$ females) from three district assemblies within the 22 metropolitan, municipal, and district assemblies. There were eight schools in the three districts. The eight schools were classified into two class A schools, two class B schools, three class C schools, and one class D school. One school each was simple randomly selected. In each school an intact class of SHS2 students was purposively selected to participate in the research. The corresponding number of students from schools A, B, C, and D were 60, 82, 68 and 90 students. Most of the 300 students (91.7\%) were within the age bracket of $16-19$ years, and $6.7 \%$ and $1.7 \%$ of the students were within the age bracket of 10-15 years and above 20 years respectively. Before data collection, we met with the selected students and briefed them on the purpose and the benefits of the research to the students and the country as a whole. The students demonstrated their willingness to participate in the research but requested that pseudonyms should be used to describe their schools and we (the researchers) promised to respect their decision.

\section{Data Collection Instruments}

One of the research instruments was a questionnaire, named; The Questionnaire on Student Knowledge and Perceptions of Mole [QSKPM] (Appendix A). QSKPM was structured on a 5-point Likert scale as 1 for strongly disagree, 2 for disagree, 3 for uncertainty, 4 for agree, and 5 for strongly agree. There were systematic and clear instructions for students on how they should respond to QSKPM. QSKPM had 21 items from which, Items 1- 2 were on general background information of students, Items 3- 20 on students' perceptions of the nature of learning mole concept, and Item 21 was an open-ended item that requested students to suggest some instructional approaches they considered to be most appropriate for teaching the mole concept. A confidentiality agreement was drafted and administered together with QSKPM to assure students of their privacy, anonymity, and confidentiality. QSKPM was constructed by the researchers based on literature, research, and teaching experiences. QSKPM was pilot tested with 40 students from two schools within the target population. The Cronbach's alpha reliability coefficient for QSKPM was calculated to be .80 .

A semi-structured interview guide was the other research instrument employed in the research. It was In-Depth Interview Guide on Students' Knowledge of the Nature of Mole 
Kenneth ADU-GYAMFI, Rejoice ELIKEM VORSAH. Gender variations favouring male students in perceived nature of learning mole concept

PROBLEMS

OF EDUCATION IN THE $21^{\text {st }}$ CENTURY Vol. 80 , No. 1,2022

[IDIGSKNM] (Appendix B). IDIGSKNM consisted of 10 items. That is, Items 1 - 6 were the main interview items before the lessons, Items 7- 9 were used after the lessons on mole concept, and Item 10 was on suggested instructional approaches for teaching mole concept. The content validity of IDIGSKNM was checked by two of our colleagues who were science educators. Internal validity of IDIGSKNM was ensured through credibility, where students had opportunities to clarify their earlier statements. The validity and reliability of IDIGSKNM were checked by recording of our interactions with students. Thereafter, trustworthiness of the interviews was ensured through the recordings of the interviews, which were transcribed, and students given the opportunities to compare the transcription to their views. Interviewer neutrality and consistent coding of the views of students on suggested instructional approaches for teaching the mole concept were used to further ensure the reliability of IDIGSKNM. The interviewers avoided asking too many questions to the students at a go. IDIGSKNM was pilot tested on three students from the target population in order to ensure reliability. Finally, we adopted credibility to ensure reliability of the interviews by engaging the students until the right responses obtained. The students were given enough time to organise their thought before responding to any question.

\section{Data Collection Procedures and Analysis}

After our interactions with the authorities of the schools, the confidentiality agreement was signed between the researchers and the students. In the second week of data collection, QSKPM was given to students, and they responded to it individually. Students responded to QSKPM within 60 minutes and returned them to the researchers. This took us a week as we spend a day in each school for the QSKPM administration. Thereafter, the data from QSKPM were analysed to establish students' perceptions of the nature of learning the mole concept among the male and female students. Based on the results from the analysis of the data from QSKPM, 10 students each from each school were identified for the focus group interviews using IDIGSKNM. That is, there were five males and five females from each school. Hence, a total of 40 students took part in the focus group interviews. However, each of the 300 students was given the opportunity to write his or her views on Item 21 on QSKPM (in your view, how should the mole concept be taught to senior high school students?) and later on Item 10 on IDIGSKNM (If another teacher is going to teach you this topic next time, what should be the best way of teaching it?) before sharing with the groups in the interviews. The written views of students were later collected to help in comparing the recorded interactions. Students' views on how best the mole concept should have been taught in the SHS are being reported here.

The aim of the research was investigated in three parts: examining the perceived nature of learning the mole concept, examining the differences in the perceived nature of learning the mole concept among male and female students, and examining the perceived suggested instructional approaches to learning the mole concept. Percentages, means, and standard deviations were used to examine the perceived nature of learning the mole concept. From the 5-point Likert scale, a mean of 5.0-3.5 indicated Agree (that is, positive perception), 3.4-2.5 was Uncertainty (that is, neutral perception), and 2.4-1.0 was Disagree (that is, negative perception). The independent-samples $t$-test was used to examine any differences in the perceived nature of learning the mole concept among male and female students. Finally, the recorded interviews were transcribed in the course of data processing. The transcribed data were open-coded and constantly compared to the established themes. Sample statements from which the themes were formed were used as supporting statements. 
Kenneth ADU-GYAMFI, Rejoice ELIKEM VORSAH. Gender variations favouring male students in perceived nature of learning mole concept

\section{Research Results}

\section{Perceived Nature of Learning the Mole Concept}

Research Question 1 sought to examine the perceptions of students on learning the mole concept. To be able to achieve this, Items 3-20 on QSKPM were used. The mean scores on students' perceptions on the mole concept are presented in Table 1.

Table 1

Students' Perceptions on Mole Concept $(N=300)$

\begin{tabular}{lcccccccc}
\hline \multirow{2}{*}{ Item } & \multicolumn{2}{c}{ Agree } & \multicolumn{2}{c}{ Disagree } & \multicolumn{2}{c}{ Uncertain } & M & SD \\
\hline 3 & $\boldsymbol{n}$ & $\%$ & $\boldsymbol{n}$ & $\%$ & $\boldsymbol{n}$ & $\%$ & & \\
\hline 4 & 250 & 83.3 & 37 & 12.3 & 13 & 4.3 & 4.0 & 1.06 \\
\hline 5 & 195 & 65.0 & 85 & 28.3 & 20 & 6.7 & 2.5 & 1.44 \\
\hline 6 & 130 & 43.3 & 152 & 50.7 & 18 & 6.0 & 3.1 & 1.35 \\
\hline 7 & 234 & 78.0 & 43 & 14.3 & 23 & 7.7 & 2.1 & 1.07 \\
\hline 8 & 123 & 41.0 & 152 & 50.7 & 25 & 8.3 & 3.2 & 1.38 \\
\hline 9 & 170 & 56.6 & 114 & 38.0 & 16 & 5.3 & 2.7 & 1.46 \\
\hline 10 & 124 & 41.3 & 161 & 53.7 & 15 & 5.0 & 3.2 & 1.42 \\
\hline 11 & 184 & 61.3 & 85 & 28.3 & 31 & 10.3 & 2.6 & 1.31 \\
\hline 12 & 252 & 84.0 & 36 & 12.0 & 12 & 4.0 & 1.9 & 1.09 \\
\hline 13 & 141 & 47.0 & 143 & 47.7 & 16 & 5.3 & 3.0 & 1.45 \\
\hline 14 & 117 & 39.0 & 157 & 52.4 & 26 & 8.7 & 3.2 & 1.40 \\
\hline 15 & 78 & 26.0 & 211 & 70.3 & 11 & 3.7 & 3.7 & 1.42 \\
\hline 16 & 150 & 50.0 & 129 & 43.0 & 21 & 7.0 & 2.9 & 1.37 \\
\hline 17 & 92 & 30.6 & 157 & 55.7 & 41 & 13.7 & 3.3 & 1.28 \\
\hline 18 & 96 & 32.0 & 171 & 57.0 & 33 & 11.0 & 3.4 & 1.37 \\
\hline 19 & 76 & 25.3 & 208 & 69.3 & 16 & 5.3 & 3.6 & 1.39 \\
\hline 20 & 84 & 28.0 & 201 & 67.0 & 15 & 5.0 & 3.6 & 1.42 \\
\hline Overall mean & 255 & 85.0 & 37 & 12.3 & 8 & 2.7 & 4.3 & 1.18 \\
\hline Not & & & & & & & 3.1 & 1.33 \\
\hline
\end{tabular}

Note: Where $N=$ the total number of students who participated in the study; $n=$ the total number of students who were uncertain, agreed, or disagreed to each item; $M=$ the perceived mean score; $S D=$ Standard deviation

On students' perceptions on teaching and learning of the mole concept in the SHS, three perspectives can be seen from the results in Table 1. That is, there were statements on the mole concept that students agreed to, and others, they disagreed to, or were uncertain on. On Item 20, of the 300 students $85.0 \%$ with highest mean of $4.3(S D=1.18)$ agreed that the mole concept can be understood better if teachers teach with teaching and learning materials (resources). This gave an indication that $15.0 \%$ of the students were uncertain or disagreed to the statement. Hence, students perceived that mole concept can be understood better if teachers teach with teaching and learning resources. On Item 3, large number of students $(83.3 \%)$ with a high mean of $4.0(S D=1.06)$ agreed that mole concept is easy and interesting. This showed that $16.6 \%$ of the students were uncertain or disagreed to the statement. Hence, majority of students perceived that mole concept is easy and interesting to learn. On Item 14, very few $(26.0 \%)$ students with a mean of $3.7(S D=1.42)$ agreed that teachers did not teach balancing of chemical equations 
Kenneth ADU-GYAMFI, Rejoice ELIKEM VORSAH. Gender variations favouring male students in perceived nature of learning mole concept

PROBLEMS

OF EDUCATION IN THE $21^{\text {st }}$ CENTURY Vol. 80 , No. 1, 2022

16

and reactions before the mole concept. This indicated that $70.3 \%$ of the students disagreed to the statement. Hence, few of the students perceived that their difficulties in learning mole concept are because they did not learn balancing of chemical equations prior to learning the mole concept. On Item 18, of the 300 students, $25.3 \%$ with a mean of $3.6(S D=1.39)$ agreed that the mole concept is the only concept they fail to understand, no matter how hard they try. This indicated that $69.3 \%$ of the students disagreed to the statement. Hence, few of the students perceived they could not understand the mole concept even if they try harder to make meaning of. On Item 19, of the 300 students, $28.0 \%$ with a mean of $3.6(S D=1.42)$ agreed that they did not show much interest in learning mole concept because they did not like it. This indicated that $67.0 \%$ disagreed to the statement. Hence, few of the students perceived to have low interest in mole concept.

The second perspective of the results from Table 1 was where students disagreed with some of the statements on the nature of learning the mole concept. The results showed that on Item 11 , of the 300 students, only $12.0 \%$ with the lowest mean of $1.9(S D=1.09)$ disagreed that mole concept requires enough mathematical background knowledge. This gave an indication that $84.0 \%$ of the students agreed to the statement. Hence, few of the students perceived that mole concept requires not enough mathematical background knowledge to enhance their conceptual understanding on the mole concept. On Item 6, of the 300 students, $14.3 \%$ with a low mean of $2.1(S D=1.07)$ disagreed that the concept of mole entails a lot including the use of Avogadro's number and amount of substance in $12 \mathrm{~g}$ of crabon-12. This gave an indication that $78.0 \%$ of the students agreed to the statement. Hence, few of the students perceived that learning of mole concept does not entail a lot.

The third perspective to the results from Table 1 was revealing as students were uncertain on 11 items on QSKPM. On Item 17, 11.0\% of the students with a mean of $3.4(S D=1.37)$ failed to agree or disagree that the mole concept is a concept which had to do with only molecules and not atoms. This indicated that $32.0 \%$ students agreed, and $57.0 \%$ students disagreed to the statement. Hence, the students were not sure of mole concept being about only molecules, but not atoms. On Item16, of the 300 students, 13.7\% with a mean of $3.3(S D=1.28)$ failed to agree or disagree that they most of the time considered mole as a mass and did not use the concept as the unit of amount of substance. This indicated that $30.6 \%$ students agreed and $55.7 \%$ disagreed to the statement. Hence, the students were not sure they considered mole as a mass and not the unit of amount of substance. On Item 7, 8.3\% of the students with a mean $3.2(S D=1.38)$ failed to agree or disagree that they preferred rote learning of the mole concept because it was too difficult. This indicated that $41.0 \%$ students agreed, and $50.7 \%$ students disagreed to the statement. Hence, the students were unsure that they preferred rote learning of mole concept because it was too difficult to understand. On Item 13, 8.7\% of the students with a mean of $3.2(S D=1.40)$ failed to agree or disagree that they had no previous knowledge relating to mole concept and found the mole concept so strange to understand. This indicated that $39.0 \%$ students agreed, and $52.4 \%$ students disagreed to the statement. Hence, the students were unsure having previous knowledge in the mole concept and found the concept so strange to understand. On Item $9,5.0 \%$ of the students with a mean of $3.2(\mathrm{SD}=1.42)$ failed to agree or disagree that they spent more time in learning mole concept than other concepts in chemistry. This indicated that $41.3 \%$ students agreed, and $53.7 \%$ students disagreed to the statement. Hence, students were unsure whether they spent more time in learning the mole concept than other chemical concepts. On Item $5,6.0 \%$ of the students with a mean of $3.1(S D=1.35)$ failed to agree or disagree that chemical names and terms in mole concept were too complex for them to understand. This indicated that $43.3 \%$ students agreed, and 50.7\% students disagreed to the statement. Hence, the students were unsure that the chemical names and terms in mole concept were too complex for them to understand. On Item 12, of the 300 students, 5.3\% with a mean of $3.0(S D=1.45)$ were uncertain that they did not master the skills of solving certain 
mathematical problems before learning mole concept and that they solved questions on mole concept through memorisation. This indicated that $47.0 \%$ students agreed, and $47.7 \%$ students disagreed to the statement. Hence, the students were unsure that they did not master the skills of solving certain mathematical problems before learning the mole concept. On Item 15, of the 300 students, $7.0 \%$ with a mean of $2.9(S D=1.37)$ failed to agree or disagree that their knowledge in atomic structure was minimal before learning the mole concept. This indicated that one-half of the students agreed and $43.0 \%$ students disagreed to the statement. Hence, the students were unsure that their knowledge in atomic structure was minimal prior to learning the mole concept. On Item $8,5.3 \%$ of the students with a mean of $2.7(S D=1.46)$ failed to agree or disagree that the mole concept was too theoretical. This indicates $56.6 \%$ students agreed and $38.0 \%$ students disagreed to the statement. Hence, the students were unsure that the mole concept was theoretical to learn. On Item 10, of the 300 students, $10.3 \%$ with a mean of 2.6 $(S D=1.31)$ failed to agree or disagree that mole concept was quite technical. This indicated that $61.3 \%$ students agreed, and $28.3 \%$ students disagreed to the statement. Hence, the students were unsure that mole concept was quite technical. On Item 4, $6.7 \%$ of the 300 students with a moderate mean of $2.5(S D=1.44)$ failed to agree or disagree that mole concept was boring when taught using inadequate teaching approaches. This gave an indication that $65.0 \%$ students agreed, and $28.3 \%$ students disagreed to the statement. Hence, the students were uncertain that mole concept could only be boring when teachers adopted inadequate teaching approaches in teaching.

In all, the results in Table 1 showed that the overall mean of $3.1(S D=1.33)$ was obtained on the perception of students about the nature of learning the mole concept. This indicated that students had uncertain perception about the mole concept and that their perception was neither positive nor negative, but neutral. The findings from Table 1 show that most of the students were uncertain about the nature of the mole concept. This means that students involved in the study could not perceive the nature of the mole concept in a similar way. However, the findings from Table 1 could not bring forth the perceptions of male and female students on the nature of learning the mole concept even if there were indication of uncertainty among them.

\section{Differences in the Perceived Nature of Learning the Mole among Male and Female Students}

Research Question 2 sought to examine whether male and female students involved in this study perceived the nature of learning the mole concept differently. A boxplot was, therefore, used to explore the perceptions of male and female students on the nature of mole concept. The results of the boxplot exploration are presented in Figure 1. 
Kenneth ADU-GYAMFI, Rejoice ELIKEM VORSAH. Gender variations favouring male students in perceived nature of learning mole concept

PROBLEMS

OF EDUCATION

IN THE $21^{\text {st }}$ CENTURY

Vol. 80 , No. 1,2022

Figure 1

A Boxplot of Male and Female Students' Perception of the Nature of the Mole Concept

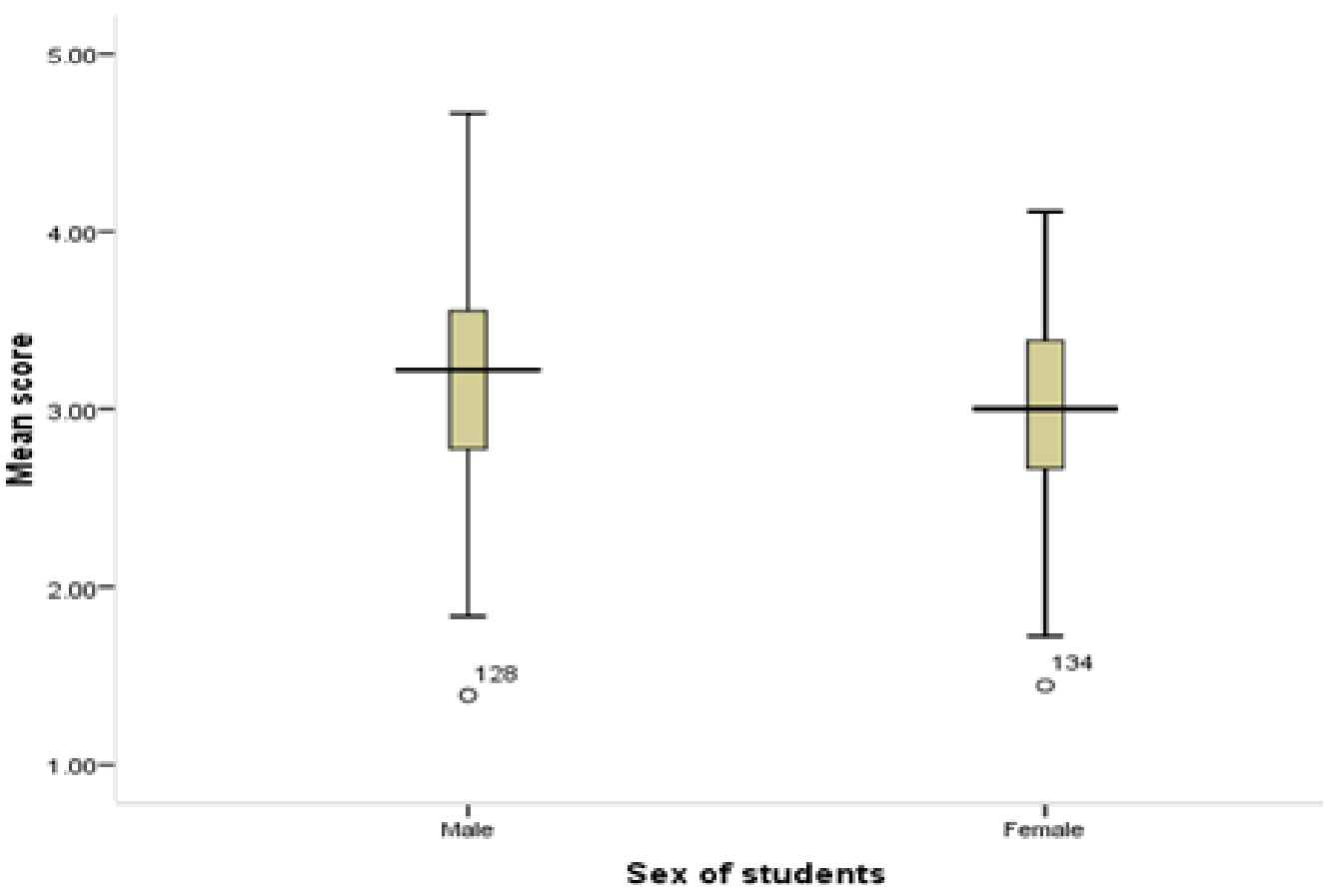

From Figure 1, the results showed there was an overlap in the mean scores of male and female students on the nature of learning the mole concept. This was because the interquartile range of male students was 14.0 and that of female students, 13.0. The results showed that at the mid $50.0 \%$, male students' perceptions on the nature of mole concept were higher than the female students. This could be due to the percentage of male students involved in the study being higher to that of the females. Though the mean scores confirmed the revelation that students were uncertain about most of the statements, but the mean score of male students' perception of the nature of mole concept $(M=57.1, S D=10.02)$ was higher than the mean score of female students' perception of the nature of mole concept $(M=54.3, S D=9.20)$. Since the boxplot could not establish the statistical difference in perceptions of male and female students on the nature of the mole concept, there was the need to use the independent-samples $t$-test.

The independent-samples $t$-test was used because, first, when the normality of the distribution of the perceived scores on nature of learning the mole concept was tested using the Kolmogorov-Smirnov statistic, it was found to be normally distributed. This was because the calculated significance of the Kolmogorov-Smirnov statistic was more than .05 (that is, $p=$ .200). Also, when the homogeneity of variance assumption was checked using Levene's test, it was not significant $(p=.324)$. This meant that the variances for the male and female students were the same and that the assumption has not been violated. Hence, the $t$-test values of equal variance assumed will be reported here. The results of the independent-samples $t$-test statistics were used to test whether there was a statistically significant difference in the perceptions of male and female students on the nature of the mole concept. The results on the independentsamples $t$-test are presented in Table 2 . 
Kenneth ADU-GYAMFI, Rejoice ELIKEM VORSAH. Gender variations favouring male students in perceived nature of learning mole concept

PROBLEMS

OF EDUCATION

IN THE $21^{\text {st }}$ CENTURY

Vol. 80 , No. 1,2022

Table 2

Results on Difference between Male and Female Students' Perceptions on Nature of Mole Concept

\begin{tabular}{lcccccc}
\hline Gender & $\boldsymbol{N}$ & $\boldsymbol{M}$ & $\boldsymbol{S D}$ & $\boldsymbol{t}$ & $\boldsymbol{d f}$ & $\boldsymbol{p}$ \\
\hline Male & 164 & 57.1 & 10.02 & 2.541 & 298 & $.012^{*}$ \\
\hline Female & 136 & 54.3 & 9.20 & & & \\
\hline Note $*$ Significant,$p<05$ & & & & &
\end{tabular}

The results from Table 2 showed that there was a statistically significant difference between the mean perception score of male students and the mean perception score of female students on the nature of learning the mole concept. This was because mean perception score of male students $(M=57.1, S D=10.02)$ was higher to the mean perception score of female students $(M=54.3, S D=9.20, t(298)=2.541, p=.012)$ on nature of learning the mole concept. This meant that most of the male students were uncertain about the nature of learning the mole concept as compared to female students. A calculated effect size (eta squared $=.021$ ) indicated that only $2.1 \%$ of the variance in the perceived nature of learning the mole concept was explained by the gender of the students. This magnitude of the differences was small.

\section{Suggested Instructional Approaches for Teaching the Mole Concept to SHS Students}

With respect to the views of students on instructional approaches that could be ideal to teaching the mole concept, students' responses on Item 21 on QSKPM and Item 10 in IDIGSKNM were examined. The results on the frequencies and percentages on alternative ways of teaching mole are presented in Table 3 .

\section{Table 3}

Percentages of Students' Views on Suggested Ways of Teaching Mole Concept to Students $(N=300)$

\begin{tabular}{lcc}
\hline Suggested ways & $n$ & $\%$ \\
\hline $\begin{array}{l}\text { Mole concept should be taught by practical means using adequate teaching and learning } \\
\text { resources like images, models, concept cartoons, and videos }\end{array}$ & 186 & 62.0 \\
\hline Mole should be taught both theoretically and practically & 14 & 4.7 \\
\hline $\begin{array}{l}\text { Mole concept should be taught by first teaching students to have mastery in mathematics, } \\
\text { chemical equation, chemical bonding, atom and other related concepts before the mole concept }\end{array}$ & 69 & 23.0 \\
\hline $\begin{array}{l}\text { Mole concept should be taught with appropriate technique to enhance students' understanding of } \\
\text { the mole concept }\end{array}$ & 11 & 3.7 \\
\hline $\begin{array}{l}\text { Mole concept should be taught by teachers solving enough calculations questions with students } \\
\text { and give them more examples to solve on their own }\end{array}$ & 14 & 4.7 \\
\hline $\begin{array}{l}\text { The mole concept should be taught using the local language and simplified the terminologies in } \\
\text { mole concept }\end{array}$ & 3 & 1.0 \\
\hline \begin{tabular}{l} 
Teaching the mole concept by well experienced chemistry teachers at the senior high school \\
\hline
\end{tabular} & 3 & 1.0 \\
\hline
\end{tabular}


Kenneth ADU-GYAMFI, Rejoice ELIKEM VORSAH. Gender variations favouring male students in perceived nature of learning mole concept

PROBLEMS

OF EDUCATION

IN THE $21^{\text {st }}$ CENTURY

Vol. 80 , No. 1,2022

From Table 3, 62.0\% of the students suggested that the teaching of the mole concept should be practical-oriented. The practical lessons should be achieved by using teaching and learning resources such as, audio-visuals, models, concept cartoons, and real laboratory apparatus. One of the students suggested practical lessons as;

Making lesson practical, will make us to be actively involved in the lesson or it will make the mole concept lesson student friendly one (School A, female student).

Another student from School A explained that;

... we were only listening to the teacher, and this makes the lesson look as if our teacher is the one learning, but we are. Our teacher did not use adequate teaching resources. From the look of things practical work will help us in learning the mole better (School A, male student).

Some of the students explained that the practical should not always be laboratory-based but can be taken as part of classroom lessons on the mole concept. This is because not all aspects of the mole concept need laboratory work for students to understand. A student from School C explained that;

I think practical lessons could help students to understand. If there are no sufficient materials, it can be demonstrated in our classroom ... (School C, female student).

Some of the students expressed some concerns about practical lessons as though important for teaching chemistry, but new ways of teaching are needed. The students perceived teachers who are experts in teaching chemistry can design their teaching using models and concept cartoons. One of the students explained that;

“... though we all call for practical works, but I think experts in teaching chemistry should come out with alternative way of teaching mole concept using what they call cartoons where the real objects are not there ... I think the expert teachers can do that (School B, male student).

From Table 3, some of the students (23.0\%) mentioned that the mole concept should be taught by first teaching students to have mastery in mathematics, chemical equation, chemical bonding, atom and other related concepts before the mole concept. Sample students' views were;

I suggest teachers teach us the background knowledge relating to the mole concept and so, we find the concept to be less difficult (School A, female student).

As the mole concept involves mathematics, I would like to have control over mathematics, so my teachers should teach the mathematics first (School C, male student).

I think our teachers should teach us any knowledge that will help us to understand mole concept first (School D, male student).

Furthermore, of the 300 students, $4.7 \%$ recommended that the mole concept should be taught by teachers solving enough calculation questions with students and thereafter, give them more examples to solve on their own. One of the students explained that;

Worked examples will help me to understand mole concept. So, I suggest our teachers teach us how to do calculations under mole and follow it up with more examples (School D, female student). 
Also, $4.7 \%$ of the students explained that teachers should teach mole through theoretical and practical means. This approach, students think would help them understand the mole concept better. One of the students explained that;

I think the teachers should be not one-sided. Both the theory and practical are needed and teachers should use the practical to help us understand the theory (School A, male student).

In another instance, $3.7 \%$ of the students explained that teachers should select and use the most appropriate instructional strategies to the teaching of the mole concept. That is, when the most appropriate instructional strategies are used by teachers, it will help students to develop the right conceptual understanding of the mole. For example;

I don't know any best way, but our teachers do. They should use the right method of teaching to teach us (School B, male student).

Though not popular among students, but $1.0 \%$ of the students explained that mole concept should be taught by teachers using local language and simple terminologies. For example,

I think our teachers should use the local language to make the terminologies easier for us (School $\mathrm{B}$, female student).

From Table 3, another $1.0 \%$ of the students explained that the mole concept should be taught by well-experienced chemistry teachers in the SHS. The reason was that well-experienced teachers have enough skills and knowledge to teach the mole concept better. One of the students explained that;

Let experience teachers teach us. Experience teachers have the experience to help students to understand the mole concept (School $\mathrm{C}$, female student).

\section{Discussion}

Findings on perceptions of students on nature of the mole concept show that the students involved in the research can improve their conceptual understanding on the mole if teachers select and use the right teaching and learning resources in teaching the concept. This is no surprise as it has been proven in a lot of research (such as Adu-Gyamfi et al., 2020) that the use of teaching and learning resources help teachers to engage students in participatory learning to help them improve their conceptual understanding of chemical concepts. Another instance where students involved in the study share common perception is mathematical knowledge which is a pre-requisite to understanding the mole concept. Though students perceive that they could do well on the mole concept even if they do not have enough mathematical knowledge. Students not perceiving that the knowledge of mathematics is an important pre-requisite to learning the mole concept could partly be the reason for their difficulties in answering the mole concept-related question in the examinations conducted by WAEC. However, chemistry students in the SHS should have the needed knowledge in mathematics because all students offering General Science, with chemistry as one of the subjects, also offer Elective-mathematics to enrich their mathematical capabilities, unlike the results of Moss and Pabari (2016) and Mweshi et al. (2019). If mole concept is easy and interesting to learn, then it should attract students and they should have positive perception, but not neutral. Chemistry teachers are therefore encouraged to look for more opportunities with which they can make mole concept more interesting and easier to learn as Rollnick et al. (2008) reported that a lot of research has looked at making teaching and learning of chemistry interesting to both teacher and student. 
Kenneth ADU-GYAMFI, Rejoice ELIKEM VORSAH. Gender variations favouring male students in perceived nature of learning mole concept

PROBLEMS

OF EDUCATION IN THE $21^{\text {st }}$ CENTURY Vol. 80 , No. 1, 2022

22

However, with respect to depth of the mole concept, students are in agreement of the perceived nature of mole concept with that of their teachers. As students appreciate that mole concept does not entail a lot, teachers (in another research) see it as a brief concept involving Avogadro's number and the amount of substance in $12 \mathrm{~g}$ of carbon-12. This could imply that teachers who are full of uncertainty in the perceived nature of mole concept (Vorsah \& Adu-Gyamfi, 2021) cannot help students overcome their learning difficulties as students are who they are in relation to what their teachers offer them. The finding that students look forward to see teachers use adequate instructional approaches and that they select the most appropriate in the teaching mole concept is significant as the concept seems difficult to students and they should be helped to overcome the difficulty. Indeed, when the right instructional strategies are not selected for teaching, students even end up developing alternative conceptions making the mole concept difficult. Hence, in this research, students' perceptions of mole concept are linked to the selection and usage of instructional strategies and teaching and learning resources. Though students are interested in learning the mole concept, their interest could in some ways be affected by the selection and usage of inappropriate instructional strategies. Chemistry teachers are, therefore, encouraged to continually select and use the most appropriate instructional strategies, such as participatory teaching and learning approach (Adu-Gyamfi et al., 2020), computer simulation games (Bilek et al., 2018), conceptual change approach (Calik et al., 2009; Priede \& Krumina, 2012), learning cycle (7E model) (Santi \& Atun, 2020), and cooperative learning approach (Avci et al., 2019) for teaching the mole concept to attract students to it. The nature of the mole concept, which entails abstractness and mathematics, could influence the concept by resulting in the difficulties encountered in the teaching and learning (Chong et al., 2019; Mweshi et al., 2019) and these, students in this research appreciate. Another finding shows that students feel they have the abilities to understand the mole concept like other chemical concept. If students have the abilities, to learn mole concept, then they should not have difficulties in it at all. And if there are difficulties in students' learning of the mole concept, then the issue could be that students are not getting the right instruction as well as instructional resources to facilitate learning. If students are confident of learning the mole concept and are prepared to put in much effort, then teachers should look for the most appropriate means of helping students to learn the mole concept. The finding that students' difficulties in learning the mole concept are because they did not learn balancing chemical equations prior to learning mole concept confirms the work of Jecelle et al. (2017) where students felt short in stoichiometry (an aspect of the mole concept) because of weaknesses in balancing chemical equations, but disconfirms the report of Bilek et al. (2018) from the literature that the mole concept is perceived to be pre-requisite for learning balancing of chemical equations. This means there is uncertainty in pre-requisite concepts to learning the mole concept and that most of the pre-requisite concepts to help students conceptualise the mole concept should be attained, and their difficulties could be related to the absence of these pre-requisite concepts. The findings show that there is a lot of uncertainty in perceptions of students on the nature of mole concept. This could be that the teachers teaching this mole concept in Ghanaian SHS are full of uncertainty in the concept (Vorsah \& Adu-Gyamfi, 2021). These findings could serve as the factors contributing to students' difficulties in learning mole concept. This is because in one breath, students are not sure of any particular aspect of the mole concept and in another, students are uncertain about considering the mole as a mass, but not the unit of amount of substance, or preferring rote learning of mole concept as it is a difficult one. This could also be that teachers' instructional strategies used in teaching mole concept have not challenged students enough to confront their alternative conceptions in the mole concept. These instances of students' uncertainty about the perceived nature of mole concept could account for students' difficulties in learning the concept. Students are further indecisive that they spend more time in learning the mole concept than other concepts in chemistry. This could be that most students do not have any knowledge of all 
the aspects of the concept of mole in the SHS curriculum and that teachers need more time to complete or rush to finish lessons within a short period of time. Students in the same way are uncertain whether they need enough time to understand the concept taught by teachers. Unless they prefer to learn by rote, which takes little time to accomplish learning the mole concept, then they will need more time to learn. Hence, students are uncertain that the chemical names, calculations, and terms in mole concept are too complex for their understanding. This could be that most students for the time being have only been introduced to basic concepts such as mole, concentration, and molar mass, which may not require complex chemical names, calculations, stoichiometry, and other terms. It is worthy of note that students' uncertainty about the mole concept is not good enough for chemistry education and could affect their subsequent learning (Driver, 1989; Gilbert et al., 1982; Johnstone, 1991) and misunderstanding on the mole (Taha et al., 2014). Students' perceptions of previous knowledge relating to the mole concept is another area of uncertainty. If students are uncertain about having related previous knowledge to the mole concept, then it will be difficult to construct new knowledge from any information on the mole concept from previous understanding (Lefa, 2014). It is not surprising that students are displaying their little conceptual knowledge in mole concept, by perceiving mole concept as a concept, which had to do with only molecules and not atoms. This is the evidence of students' ignorance about conceptual knowledge on the mole concept and the development of their perception from their lack of conceptual knowledge about pre-requisite concepts (Treagust et al., 2000; Tsoi et al., 1998). Nonetheless, this prior concept is the key factor in understanding chemical concepts, and teachers expect students to possess it before learning the mole concept.

There is a statistically significant difference between male and female students on the perceived nature of learning the mole concept, which is full of uncertainty. In other words, the gender of students influences the kind of perception students have about the mole concept. Though the magnitude of the differences is small, the current research brings to light that the perceived nature of learning the mole concept being biased by the gender of the SHS students cannot be ignored. Also, male students are more uncertain in their perceptions about the mole concept compared to their female counterparts. This finding has added to Majere et al. (2017) study, which shows a statistically significant difference between male and female students' perceptions and reflections on academic achievement of chemical concepts. Also, it may stem from poor mathematical background that affects students' learning of chemical concepts (Moss \& Pabari, 2016). Hence, such a difficulty may have resulted in a statistically non-significant difference in students' perceptions and academic achievements on the mole concept (Mukuta \& Banda, 2019).

There are several perceived ways of teaching mole concept for students to understand. Some of these ways include the use of models, concept cartoons, multimedia, videos, and mastery learning instructional strategy. The rest are inquiry-based activities, inductive teaching method, and learning cycles. The findings show that students suggest that the teaching of the mole concept should be practical. The practical lessons could be achieved using teaching and learning resources that are ICT-based or not. Examples such as computers, animations, models, and real apparatus are assumed to help facilitate teaching and learning. These teaching and learning resources would enhance the effective understanding of the concept by students (Ajayi \& Ogbeba, 2017). There is, therefore, the need for curriculum developers to recommend the most appropriate instructional strategies with teaching and learning resources that will help chemistry teachers facilitate the teaching of the mole concept within the practical approaches. Though not popular, students suggest the use of local language in teaching mole concepts. This could be that language is not a barrier to learning the mole concept as reported elsewhere (Suchting, 1998) or the language they have acquired over the years (Indriyanti \& Barke, 2017) could be affecting their perception of learning the mole concept. It is, therefore, necessary for chemistry educators and researchers to look at the issues of language and learning of chemical 
Kenneth ADU-GYAMFI, Rejoice ELIKEM VORSAH. Gender variations favouring male students in perceived nature of learning mole concept

PROBLEMS

OF EDUCATION IN THE $21^{\text {st }}$ CENTURY Vol. 80 , No. 1, 2022

concepts once again. It could be that the scientific language is the challenge (Barke et al., 2009; Wertsch, 2000), but not the use of local language in teaching chemical concepts. The Ministry of Education through the National Council for Curriculum and Assessment should, therefore, reconsider any intent of using the local language in teaching science-related subjects such as chemistry in the SHS in Ghana. Strong background knowledge and experiences in mathematical and other chemical concepts relating to the mole are perceived to help students develop the correct conceptual understanding in the concept. Students, therefore, suggest that one other best way of teaching the mole concept is having previous knowledge and experiences in mathematics, chemical equations, and chemical bonding. If students have suggested that one other best way of teaching the mole concept is taking care of previous experience, then chemistry educators should take advantage of that (Lefa, 2014) to help students. The uncertainty among students becomes evident here as they perceive that mathematical knowledge is not a pre-requisite for learning the mole concept but suggest that teachers should help them to attain mastery in mathematics to aid in knowledge construction of the mole concept. There is, therefore, the need for chemistry educators and researchers to further investigate the place of mathematical knowledge in influencing the perceptions and conceptual understanding of senior high school students on the mole concept.

\section{Conclusions and Implications}

The study has shown that there are a lot of instances where both male and female students are uncertain about the nature of learning the mole concept. For example, students are uncertain of their preference for rote learning of the mole concept as a difficult concept. Notwithstanding, the students' uncertainty in the perceived nature of learning the mole concept, the current study has added to the literature that students are in agreement of uncertainty with their teachers that the mole concept is a shallow area in chemistry, but it is a broad one that entails a lot, not just Avogadro's number and the amount of substance in 12g of carbon-12. The Ministry of Education through the Ghana Education Service should organise teacher professional development programmes where chemistry educators will engage teachers in teaching chemistry in SHS to the true depth of the mole concept in the SHS curriculum to stimulate students' perceptions. In all, male students are more uncertain in the nature of learning the mole concept compared to their female counterparts. However, both male and female students have interest in learning chemical concepts. This is evident by the fact that students perceived mole concept as an easy and interesting area in chemistry. Though mole concept is abstract and mathematical, students have confidence learning the concept. The study has once again added to the literature on chemistry education that students see mole concept as easy and interesting chemistry notwithstanding their difficulties in examination items on the concept. Though students are uncertain, but male students are most uncertain on the nature of learning the mole concept compared to their female counterparts, hence, teachers teaching chemistry in the SHS should create an environment conducive to male and female students to overcome their uncertainty on the perceived nature of learning the mole concept. Also, curriculum developers should recommend cooperative and participatory teaching-learning approaches that consider male and female students' difference for teaching chemistry in the SHS.

\section{Declaration of Interest}

The authors declare no competing interest. 


\section{References}

Adu-Gyamfi, K., Ampiah, J. G., \& Agyei, D. D. (2020). Participatory teaching and learning approach. A framework for teaching redox reactions at high school level. International Journal of Education and Practice, 8(1), 106-120. https://doi.org/10.18488/journal.61.2020.81.106.120

Ajayi, V. O., \& Ogbeba, J. (2017). Effect of gender on senior secondary chemistry students' achievement in stoichiometry using hands-on activities. American Journal of Educational Research, 5(8), 839842. http://dx.doi.org/10.12691/education-5-8-1

Avci, F., Kirbasiar, F. G., \& Sesen, B. A, (2019). Instructional curriculum based on cooperative learning related to the structure of matter and its properties: Learning achievement, motivation and attitude. South African Journal of Education, 39(3), 1-14. https://files.eric.ed.gov/fulltext/EJ1228981.pdf

Barke, H. D., Hazari, A., \& Yitbarek, S. (2009). Students' misconceptions and how to overcome them. In Misconceptions in Chemistry (pp. 21-36). Springer.

Bilek, M., Nodzynska, M., Kopek-Putala, W., \& Zimak-Piekarczyk, P. (2018). Balancing chemical equations using sandwich making computer simulation games as a supporting teaching method. Problems of Education in the $21^{\text {st }}$ Century, 76(6), 779799. https://dx.doi.org/10.33225/pec/18.76.779

Calik, M., Ayas, A., \& Coll, R. K. (2009). Investigating the effectiveness of an analogy activity in improving students' conceptual change for solution chemistry concepts. International Journal of Science and Mathematics Education, 7, 651-676. https://doi.org/10.1007/s10763-008-9136-9

Chong, S. H., Goolamally, N., \& Leong, K. E. (2019). Post-Secondary science students' understanding on mole concept and solution concentration. Universal Journal of Educational Research, 7(4), 9861000. http://dx.doi.org/10.13189/ujer.2019.070410

Dahsah, C. \& Coll, R. K. (2007). Thai grade 10 and 11 studentse conceptual understanding and problemsolving ability in stoichiometry. Research in Science and Technology Education, 25, 227-241. https://doi.org/10.1080/02635140701250808

Damaso, K., \& Banda, A. (2019). Effect of concept mapping on learner achievement on mole concept. International Journal of Advanced Research and Publications, 3(11), 18-26.

Doulík, P., \& Škoda, J. (2009). Challenges of contemporary science education. Problems of Education in the $21^{\text {st }}$ Century, 11, 45-50. http://www.scientiasocialis.lt/pec/node/208

Driver, R. (1989). Students' conceptions and the learning of science. International Journal of Science Education, 11(5), 481-490. https://doi.org/10.1080/0950069890110501

Ebbing, D. D., \& Gammon, S. D. (2017). General chemistry (11 ${ }^{\text {th }}$ ed.). Cengage Learning EMEA.

Furio, C., Azcona, R., \& Guisasola, J. (2002). The learning and teaching of the concepts 'amount of substance' and 'mole': A review of literature. Chemistry Education: Research and Practice in Europe, 3(3), 277-292.

Ghana Statistical Service. (2021). 2021 population and housing census. Press release on provisional results. Author. https://statsghana.gov.gh/gssmain/storage/img/infobank/2021\%20PHC\%20 Provisional\%20Results\%20Press\%20Release.pdf

Gilbert, J., Osborne, R. J., \& Fensham, P. J. (1982). Children's science and its consequences for teaching. Journal of Science Education, 66(4), 623-633. https://doi.org/10.1002/sce.3730660412

Goes, L. F., Nogueira, K. S. C., \& Fernandez, C. (2020). Limitations of teaching and learning redox reactions: A systematic review. Problems of Education in the $21^{\text {st }}$ Century, 78(5), 698-718. https://doi.org/10.33225/pec/20.78.698

Hafsah, T., Rosnani, H., Zurida, I., Kamaruzaman, J., \& Yin, K. Y. (2014). The influence of students' concept of mole, problem representation ability and mathematical ability on stoichiometry problem solving. Scottish Journal of Arts, Social Sciences and Scientific Studies, 3, 28-99.

Indriyanti, N. Y., \& Barke, H.-D. (2017). Teaching the mole concept with sub-micro level: Do the students perform better? In: AIP Conference Proceedings 1868, 030002 (2017). https://doi.org/10.1063/1.4995101

Jecelle, A. Jaranilla, Maricar, S., Prudente, \& Perez, D. R. (2017). Exploring students' conceptions on stoichiometry using SCQS and VCQS. Asia Pacific Journal of Education, Arts \& Sciences, 4(2), 45-51. 
Kenneth ADU-GYAMFI, Rejoice ELIKEM VORSAH. Gender variations favouring male students in perceived nature of learning mole concept

PROBLEMS

OF EDUCATION IN THE $21^{\text {st }}$ CENTURY Vol. 80 , No. 1, 2022

26

Johnstone, A. H. (1991). Why is science difficult to learn? Things are seldom what they seem. Journal of Computer Assisted Learning, 7(2), 75-83. https://doi.org/10.1111/j.1365-2729.1991.tb00230.x

Kamaruddin, M. I., Ambrose, M. S., \& Ling, H. L. (2003). The mastery of chemistry and its relationship with the solution of the mole concept problem: A case study among second year students of chemistry education at Faculty education. University Technology Malaysia. http://eprints.utm. my/2338/112.Meor.pdf

Klinger, S., \& Findenig, I. (2014). Making gender a subject of discussion - A mission (IM) possible in the $21^{\text {st }}$ century?! Students of educational studies as an example within the context of academia. Problems of Education in the $21^{\text {st }}$ Century, 60, 101-113. https://dx.doi.org/10.33225/pec/14.60.101

Lefa, B. (2014). The Piaget theory of cognitive development: An educational implication. Journal of Educational Psychology, 1(1), 1-8.

Majere, I. S. M., Role, E., \& Makewa, L. N. (2017). Gender Disparities in self-concept, attitude and perception in physics and chemistry. Atlas Journal of Science Education, 2(1), 61-69. http://dx.doi.org/10.5147/ajse.v2i1.77

Mburu, D. N. P., \& Nyagah, G. (2012). Effects of gender role portrayal in textbooks in Kenyan primary schools, on pupils' academic aspirations. Problems of Education in the $21^{\text {st }}$ Century, 47, 100-109. https://dx.doi.org/10.33225/pec/12.47.100

Mensah, A., Morabe, O. N., \& Golightly, A. (2016, October 23-28). Teaching chemical equilibrium through conceptual change approach: A synthesis and analysis of the literature. A paper presented at ISTE International Conference on Mathematics, Science and Technology Education, Mopani Camp, Kruger National Park, Limpopo, South Africa.

Ministry of Education. (2010). Teaching syllabus for chemistry (senior high school 1-3). Author.

Moss, K., \& Pabari, A. (2016). The mole misunderstood. New Directions in the Teaching of Physical Sciences, 6, 77-86. https://doi.org/10.29311/ndtps.v0i6.392

Mukuta, M., \& Banda, A. (2019). The effect of numeracy on attitude and conceptual understanding of mole concept by Grade 11 students. International Journal of Advanced Research and Publications, 3(9), 16-23. https://www.ijarp.org/published-research-papers/sep2019/The-Effect-Of-NumeracyOn-Attitude-And-Conceptual-Understanding-Of-Mole-Concept-By-Grade-11-Students.pdf

Mulford, D. R., \& Robinson, W. R. (2002). An inventory for alternate conceptions among firstsemester general chemistry students. Journal of Chemical Education, 79(6), 739-744. https://pubs.acs.org/doi/abs/10.1021/ed079p739

Mweshi, E., Munyati, O., \& Nachiyunde, K. (2019). Teachers' mole concept pedagogical content knowledge: Developing the model for the mole concept content representations framework. Journal of Education and Practice, 10(8), 51-65. https://doi.org/10.7176/JEP/10-8-08

Okebukola, P. (2005). Quality assurance in teacher education: The role of faculties of education in Nigerian universities. A report presented to the committee of deans of Education of Nigerian Universities.

Ozmen, H. (2007). The effectiveness of conceptual change texts in remediating high school students' alternative conceptions concerning chemical equilibrium. Asia Pacific Education Review, 8(3), 413-425.

Petrucci, R. H., Herring, F. G., Madura, J. D., \& Bissonnette, C. (2017). General chemistry: Principle \& modern applications $\left(11^{\text {th }} \mathrm{ed}\right.$.). Person Canada.

Priede, D., \& Krumina, A. (2012). A Conceptual approach to learning chemistry in professional secondary school in Latvia. US-China Education Review B 1, 31-40. https://files.eric.ed.gov/fulltext/ ED531658.pdf

Rollnick, M., Bennett, J., Rhemtula, M., Dharsey, N., \& Ndlovu, T. (2008). The place of subject matter knowledge in pedagogical content knowledge: A case study of South African teachers teaching the amount of substance and chemical equilibrium. International Journal of Science Education, 30(10), 1365-1387. https://doi.org/10.1080/09500690802187025

Santi, M. T., \& Atun, S. (2020). Learning activities based on learning cycle 7E model: Chemistry teachers' perspective. Advances in Social Science, Education and Humanities Research, 541, 234-240. file://C:/Users/HP/Downloads/125954758.pdf

Sarkodie, P. A., \& Adu-Gyamfi, K. (2015). Improving students' performance in naming and writing structural formulae of hydrocarbons using ball and stick models. Bulgarian Journal of Science Education, 24(2), 203-219. 
Shebu, G. (2015). The effect of problem-solving instructional strategies on students' learning outcomes in senior secondary school chemistry. IOSR Journal of Research \& Method in Education, 5(1), 10-14. https://doi.org/10.9790/7388-05111014

Sirhan, G. (2007). Learning difficulties in chemistry: An overview. Journal of Turkish Science Education, $4(2), 2-20$.

Suchting, W. (1998). Constructivism deconstructed. In M. Mathews (Ed.), Constructivism in science education (pp. 61-92). Springer. https://doi.org/10.1007/978-94-011-5032-3_4

Taha, H., Hashim, R., Ismail, Z., Jusoff, K., \& Yin, K. Y. (2014). The influence of students' concept of mole, problem presentation ability and mathematical ability on stoichiometry problem solving. A paper presented at the 2014 WEI International Academic Conference Proceedings, Bali, Indonesia.

Treagust, D., Nieswandt, M., \& Duit, R. (2000). Sources of students' difficulties in learning chemistry. Chemical Education, 11(2), 228-235. http://dx.doi.org/10.22201/fq.18708404e.2000.2.66458

Tsoi, R. M. F., Goh, N. K., \& Chia, L. S. (1998). Some suggestions for the teaching of the mole concept. In M. Waas (Ed.), Enhancing learning: Challenge of integrating thinking and information technology into the curriculum: Proceedings of the 12th Annual Conference of the Educational Research Association (pp. 778-785). Educational Research Association. http://hdl.handle.net/10497/14982

Vorsah, R. E., \& Adu-Gyamfi, K. (2021). High school chemistry teachers' perspectives and practices on teaching mole concept. European Journal of Education Studies, 8(2), 132-151. https://doi.org/10.46827/ejes.v8i2.3556

Voska, K. W., \& Heikkinen, H. W. (2000). Identification and analysis of student conceptions used to solve chemical equilibrium problems. Journal of Research in Science Teaching: The Official Journal of the National Association for Research in Science Teaching, 37(2), 160-176. https:// doi.org/10.1002/(SICI)1098-2736(200002)37:2\%3C160::AID-TEA5\%3E3.0.CO;2-M

Wertsch, J. V. (2000). Vygotsky's two minds on the nature of meaning. In C. D. Lee \& P. Smagorinsky (Eds.), Vygotskian perspectives on literacy research: Constructing meaning through collaborative inquiry (pp. 19-30). Cambridge University Press.

West Africa Examinations Council. [WAEC]. (2015). Chief examiner's report: general science programme: May/June West Africa senior secondary certificate examination. Author.

West Africa Examinations Council. [WAEC]. (2016). Chief examiner's report: general science programme: May/June West Africa senior secondary certificate examination. Author.

West Africa Examinations Council. [WAEC]. (2017). Chief examiner's report: General science programme: May/June West Africa senior secondary certificate examination. Author.

Zephrinus, C., \& Phoebe, M. I. (2015). Resolving Nigerian secondary school students' learning difficulties in nuclear chemistry using computer animation solutions. Procedia-Social and Behavioral Sciences, 176, 1034-1040.

\section{APPENDIX A}

\section{THE QUESTIONNAIRE ON STUDENT KNOWLEDGE AND PERCEPTIONS OF MOLE}

Dear student,

The purpose of this questionnaire is to explore perceptions students have about mole concept. It is for academic purpose only. Your assistance in providing the information is kindly requested by completing the attached questionnaire. There is no wrong or right response.

Please be assured that the information that you provided in the survey will be treated confidential.

\section{SECTION A: BACKGROUND INFORMATION;}

Tick only one

1. Sex of respondent

[ ] Male

[ ] Female

2. Age

[ ] 10- 15years

[ ] 16-19years

[ ] 20 years and above 
Kenneth ADU-GYAMFI, Rejoice ELIKEM VORSAH. Gender variations favouring male students in perceived nature of learning mole concept

PROBLEMS

OF EDUCATION IN THE $21^{\text {st }}$ CENTURY Vol. 80 , No. 1,2022

SECTION B: STUDENTS' PERCEPTIONS OF MOLE CONCEPT

Use the scale below to indicate the extent to which you agree or disagree with the following statements. (Please, provide responses where appropriate).

KEY

$\mathrm{SA}=$ Strongly Agree, $\mathrm{A}=$ Agree, $\mathrm{UN}=$ Uncertain, $\mathrm{D}=$ Disagree, $\mathrm{SD}=$ Strongly Disagree

\begin{tabular}{|c|c|c|c|c|c|}
\hline Statement & SD & $\mathbf{D}$ & $\mathbf{U N}$ & $\mathbf{A}$ & SA \\
\hline 3. Mole concept is easy and interesting & & & & & \\
\hline $\begin{array}{l}\text { 4. Mole concept is boring when taught using inadequate } \\
\text { teaching approaches }\end{array}$ & & & & & \\
\hline $\begin{array}{l}\text { 5. The chemical names and terms in mole concept are too } \\
\text { complex for me to understand }\end{array}$ & & & & & \\
\hline $\begin{array}{l}\text { 6. The concept of mole entails a lot such that in one way, it is } \\
\text { compared with Avogadro's number of particles, while in the } \\
\text { second way it is necessary to compare to mass of substance } \\
\text { contained in the mole to } 12 \mathrm{~g} \text { of isotope carbon- } 12 \text {. }\end{array}$ & & & & & \\
\hline $\begin{array}{l}\text { 7. I prefer rote learning of the mole concept because it is too } \\
\text { difficult to understand }\end{array}$ & & & & & \\
\hline 8. Mole concept is too theoretical & & & & & \\
\hline $\begin{array}{l}\text { 9. I spent more time in learning mole concept than other } \\
\text { concepts in chemistry }\end{array}$ & & & & & \\
\hline 10. Mole concept is quite technical. & & & & & \\
\hline $\begin{array}{l}\text { 11. The mole concept requires enough mathematical background } \\
\text { knowledge. }\end{array}$ & & & & & \\
\hline $\begin{array}{l}\text { 12. I did not master the skills of solving certain mathematical } \\
\text { problems before learning mole concept and so, I do } \\
\text { memorization to solve questions in mole concept. }\end{array}$ & & & & & \\
\hline $\begin{array}{l}\text { 13. I had no previous knowledge relating to mole concept and so } \\
\text { I find mole concept so strange to understand }\end{array}$ & & & & & \\
\hline $\begin{array}{l}\text { 14. My teacher did not teach balancing of chemical equations } \\
\text { and reactions before the mole concept, making it difficult to } \\
\text { learn mole concept. }\end{array}$ & & & & & \\
\hline $\begin{array}{l}\text { 15. My knowledge in atomic structure was minimal before I } \\
\text { was taught the mole concept }\end{array}$ & & & & & \\
\hline $\begin{array}{l}\text { 16. I, most of the time, consider mole as a mass, and I did not } \\
\text { use it as a unit of the amount of substance. }\end{array}$ & & & & & \\
\hline $\begin{array}{l}\text { 17. The mole concept is a concept which had to do with only } \\
\text { molecules and not atoms. }\end{array}$ & & & & & \\
\hline $\begin{array}{l}\text { 18. The mole concept is the only concept I always fail to } \\
\text { understand, no matter how hard I try. }\end{array}$ & & & & & \\
\hline $\begin{array}{l}\text { 19. I do not show much interest in learning mole concept } \\
\text { because I don't like it }\end{array}$ & & & & & \\
\hline $\begin{array}{l}\text { 20. The mole concept can be understood better if teachers teach } \\
\text { with teaching learning materials. }\end{array}$ & & & & & \\
\hline
\end{tabular}

\section{SECTION C: RECOMMENDATIONS ON HOW TO TEACH THE MOLE CONCEPT TO} STUDENTS

21. In your views, how should the mole concept be taught by teachers to Senior High School students? 


\section{APPENDIX B}

\section{IN-DEPTH INTERVIEW GUIDE ON STUDENTS' KNOWLEDGE OF THE NATURE OF MOLE \\ Introduction}

The researcher is with the Department of science Education, University of Cape Coast pursuing MPhil. Science Education and researching into "challenges facing the teaching and learning of mole concept" as part of her academic work. Your co-operation and support are highly needed if this research project is to be successful. You are kindly requested to make some time out of your busy schedules to participate in the study and as accurately and honestly respond to the issue to your best of ability. You are greatly assured that your anonymity and confidentiality are guaranteed. Information provided will be treated with the strictest confidence and the result of this research work will not be used in any way detrimental to your interest. Thank you very much for agreeing to be a part of this research work.

\section{Interview Questions}

\section{Before the lesson on mole concept}

1. Have you been introduced to mole concept?

2. What are some of the difficulties you encounter when learning mole concept?

3. Which aspects of mole concept do you face these difficulties in?

4. What account for these difficulties?

5. How do you overcome these difficulties?

6. What are your expectations in going into this lesson on mole concept?

After the lesson on mole concept

7. Did you meet your expectations?

8. Any reason for meeting or not meeting your expectations?

9. Are there some difficulties in this lesson?

10. If another teacher is going to teach you this topic next time, what should be the best way of teaching it?

Cite as: Adu-Gyamfi, K., \& Elikem Vorsah, R. (2022). Gender variations favouring male students in perceived nature of learning mole concept. Problems of Education in the $21^{\text {st }}$ Century, 80(1), 9-29. https://doi.org/10.33225/pec/22.80.09

Kenneth Adu-Gyamfi

(Corresponding author)
$\mathrm{PhD}$, Lecturer, Department of Science Education, University of Cape Coast, Ghana.

E-mail: kenneth.adu-gyamfi@ucc.edu.gh

ORCID: https://orcid.org/0000-0002-1959-3702

Rejoice Elikem Vorsah
MSc (Science Education), Department of Science Education, Faculty of Science and Technology Education, University of Cape Coast, Ghana.

E-mail: vorsahrejoice024@gmail.com 